\title{
Examining early marriage in India: Qualitative findings
}

\author{
Neelanjana Pandey \\ Population Council \\ Komal Saxena \\ Andrea J. Melnikas \\ Population Council
}

Follow this and additional works at: https://knowledgecommons.popcouncil.org/departments_sbsr-pgy

Part of the Demography, Population, and Ecology Commons, Family, Life Course, and Society Commons, International Public Health Commons, and the Women's Health Commons How does access to this work benefit you? Let us know!

\section{Recommended Citation}

Pandey, Neelanjana, Komal Saxena, and Andrea J. Melnikas. 2019. "Examining early marriage in India: Qualitative findings." New York: Population Council. 


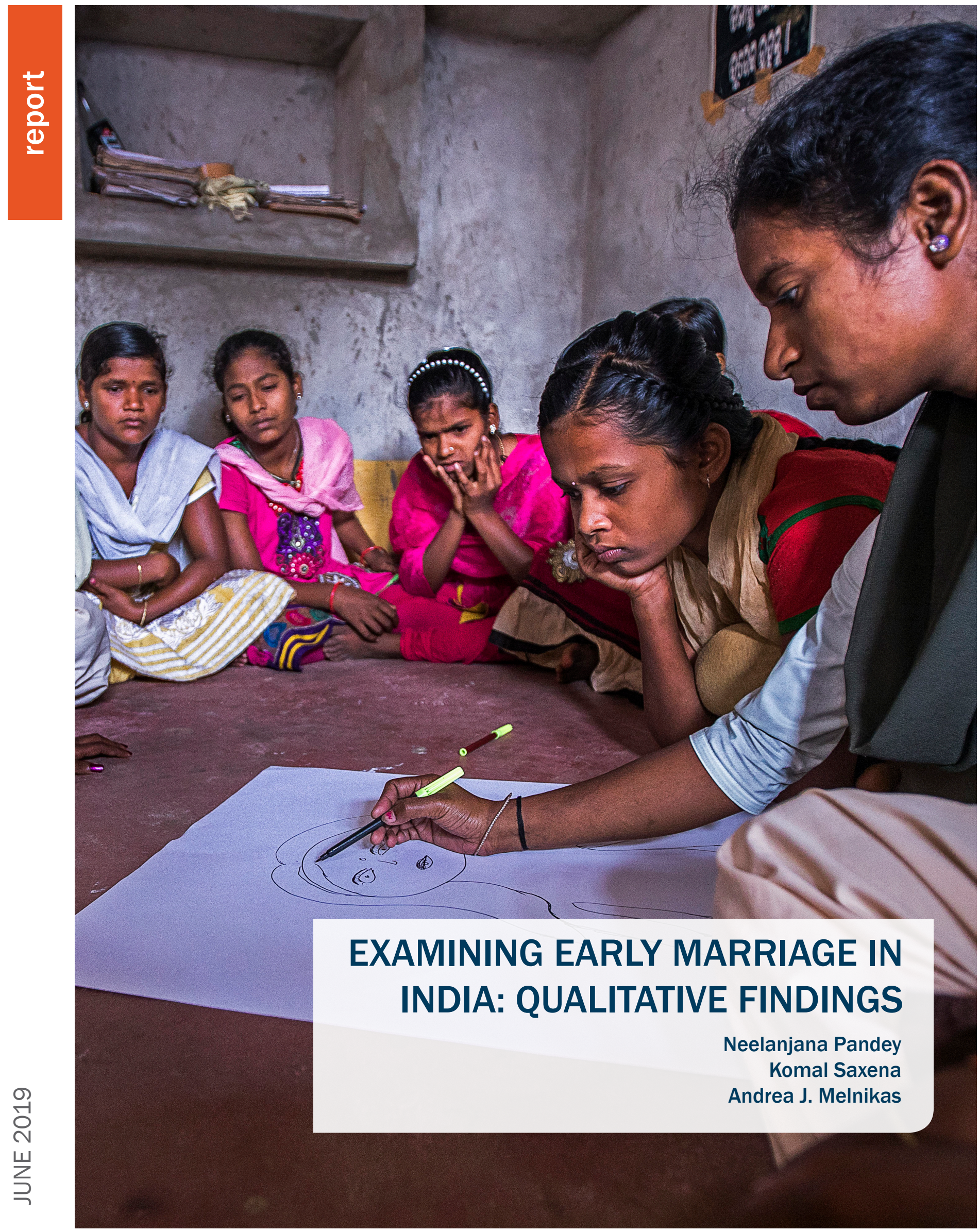

11. 


\section{Population
counchl \\ Ideas. Evidence. Impact.}

The Population Council confronts critical health and development issues-from stopping the spread of HIV to improving reproductive health and ensuring that young people lead full and productive lives. Through biomedical, social science, and public health research in 50 countries, we work with our partners to deliver solutions that lead to more effective policies, programs, and technologies that improve lives around the world. Established in 1952 and headquartered in New York, the Council is a nongovernmental, nonprofit organization governed by an international board of trustees.

Population Council India

Zone 5A, Ground Floor

India Habitat Centre, Lodi Road

New Delhi, India 110003

email: pubinfo@popcouncil.org

popcouncil.org

Suggested citation: Pandey, Neelanjana, Komal Saxena, and Andrea J. Melnikas. 2019. "Examining Early Marriage in India: Qualitative Findings.” New York: Population Council.

Photo credit: Photo courtesy of VHAI @ 2017.

(C) 2019 The Population Council, Inc. 


\section{Table of Contents}

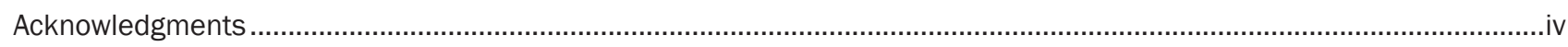

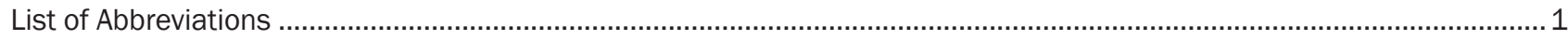

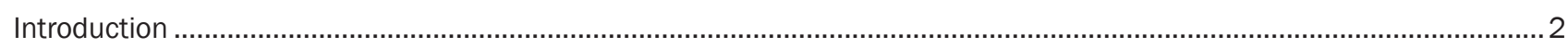

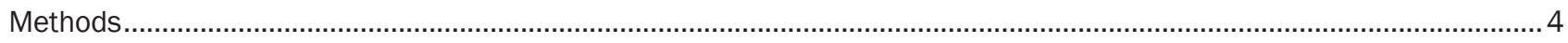

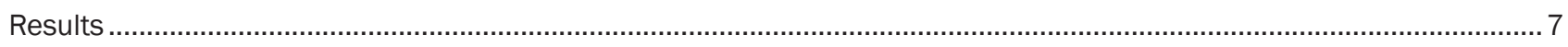

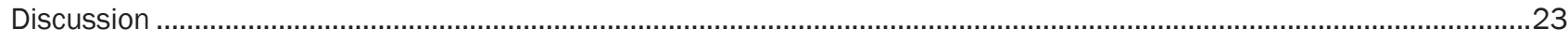

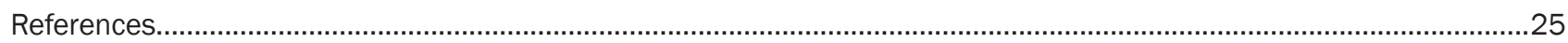




\section{Acknowledgments}

This research was conducted as part of the More than Brides Alliance (MTBA), which consists of Save the Children Netherlands, Oxfam Novib, Simavi, and the Population Council. With funding from the Dutch Ministry of Foreign Affairs, MTBA implements the "Marriage: No Child's Play" program (2016-20), which aims to reduce child marriage and its adverse effects on young women and girls. The program has been implemented in India, Malawi, Mali, Niger, and Pakistan.

At the Population Council, several colleagues have lent support in both the technical and administrative aspects of the project, and we acknowledge their contributions. We would like to thank Sajeda Amin, K.G. Santhya, and Grace Saul for providing support in carrying forward project activities and the development of this report.

We thank our partners in India for the important work they do and for implementing the intervention activities. We also would like to thank the girls and parents who generously gave of their time to participate in this research. 


\section{List of Abbreviations}

ASHA

AWW

Accredited Social Health Activist

FGD

Anganwadi worker

MTBA

Focus group discussion

SRHR

More Than Brides Alliance

Sexual and reproductive health and rights 


\section{Introduction}

The proportion of girls marrying before the age of 18 in India has nearly halved in the last decade as evident from National Family and Health Survey 2015-16 (IIPS and ICF, 2017). UNICEF (2018) suggests that this decline has contributed significantly to the observed global decline in child marriage. Despite this 43 percent reduction in prevalence of child marriage (from 47 percent to 27 percent), India is home to about 1.5 million child brides. Policy and programmatic efforts have shown mixed effects on early marriage (Nanda and Das 2015), with considerable variation existing both between and within states, and between different socioeconomic groups (Parsons and McCleary-Sills 2014; UNICEF 2018).

A number of studies have examined the drivers of early marriage in India (Santhya et al. 2006; Raj 2010), which include economic insecurity and the financial burden of raising daughters, social norms about early marriage that contribute to anxiety about finding a suitable spouse before it is “too late," and strong gender norms about girls' sexuality as well as the benefits of girls' education. While previous research has identified the complex drivers of early marriage, site-specific, careful diagnostic research is needed to better understand the effectiveness of interventions to prevent it, the perceived acceptability of programs, and potential pathways to success.

This report primarily uses qualitative data generated as part of an impact evaluation of the More Than Brides Alliance (MTBA) project. The MTBA evaluation uses a mixed-method design to evaluate the effectiveness of interventions designed and implemented by local partner organizations aiming to delay marriage and working at multiple levels-individual, family, and community. We report on both baseline data from surveys with adolescent girls and focus group discussions (FGDs) with adolescent girls and parents of adolescent girls. Full baseline results are available elsewhere (Basu et al. 2017).

\section{Objectives}

The objectives of the qualitative assessment were to explore the perceptions of adolescent girls and their parents with respect to norms and practices surrounding marriage, reasons for early marriage, and possible alternatives to early marriage for girls. Parents' perspectives on community pressure were explored, as well as their awareness about laws and punishment, which may mitigate the risk of early marriage.

Specifically, the assessment sought to better understand:

- Awareness of laws and acts prohibiting early marriage and how they have been accepted or challenged in the community.

- The accessibility of educational opportunities, livelihood opportunities, and safe spaces that might mitigate the risk of early marriage for adolescent girls.

- Parents' perceptions of community norms concerning marriage age and perceived risks if girls remain unmarried until age 18.

\section{The Intervention}

The More Than Brides Alliance (MTBA) implements the “Marriage: No Child's Play" program (2016-20) in India, Malawi, Mali, Niger, and Pakistan. The MTBA is a holistic program that addresses early marriage through multiple strategies, including: sexual and reproductive health and rights (SRHR), livelihoods, education, and prevalent community social norms around marriage. The MTBA program operates at multiple levels (girl, family, community, block, and district) to address individual, familial, and structural barriers to reducing child marriage in these communities.

\section{Structure of the Report}

This report is divided into three sections based on the levels of influence relevant to early marriage in these settings. Figure 1 shows how different levels included in this research address early marriage. In the first section, we look at the legal environment in which these programs operate by examining participants' awareness of laws, acts, and programs related to early marriage prevention and how awareness of such laws might influence the timing of girls' marriage. Next, we focus on the family environment and parental expectations for girls as important drivers of child 
Figure 1. Levels of influence examined in report

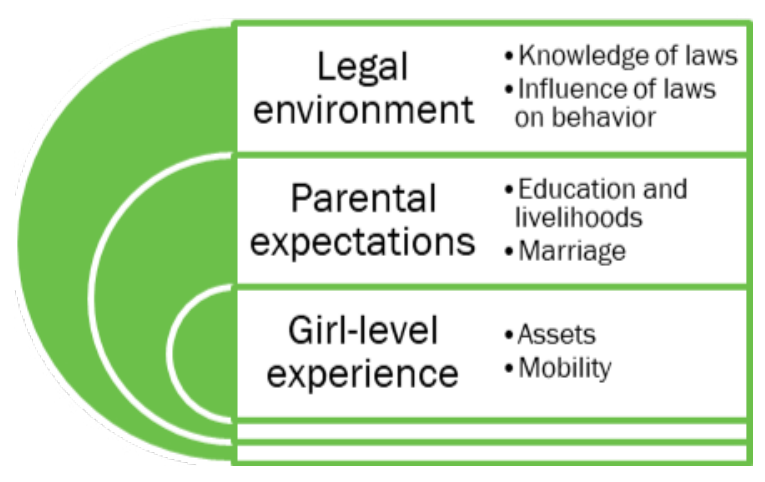

marriage. Among parents, we explore girls' education, livelihood opportunities, perceptions of agency and mobility, and expectations for marriage. We then focus on girls, examining their experiences regarding education, livelihoods, mobility, and safety, as well as their knowledge of SRHR services.

Finally, we summarize the main findings of this study and provide programmatic recommendations based on the research. 


\section{Methods}

\section{Study Setting}

In 2016, a quantitative baseline assessment was conducted in rural blocks of nine districts from the four states included in the MTBA evaluation (Bihar, Jharkhand, Odisha, and Rajasthan). Table 1 presents overall demographic data from baseline surveys of girls aged 12-19 in each state. For qualitative data collection, we selected the following sites for FGDs: Gaya and Sitamarhi (Bihar); Deoghar and Dumka (Jharkhand); Ganjam, Kandhamal, and Nuapada (Odisha); and Jodhpur and Tonk (Rajasthan).

\section{Study Design}

Qualitative data were collected following the baseline survey (Basu et al. 2017) to explore in greater depth the community and parental norms around marriage and contextual factors contributing to the practices of early marriage. Qualitative instruments were also designed to explore alternatives to marriage and to explore knowledge and perceptions of child marriage laws and acts.

\section{Study Instruments}

\section{Focus group discussions with adolescent girls}

FGDs were held in separate groups of unmarried and married adolescent girls. Topics included safe spaces, access to SRHR services, awareness of child-protection systems, the legal environment, and other community-based structures available to adolescent girls. A total of 15 FGDs were conducted in the four states: 10 with the unmarried girls (2 in each state of Bihar, Jharkhand, and Rajasthan, and 4 in Odisha) and 5 with married young girls (one in each state of Bihar, Jharkhand, and Rajasthan, and 2 in Odisha). Program implementation in Odisha is carried out in three districts by two implementing partners, thus more FGDs were conducted in order to understand program implementation and contextual differences.

\section{Focus group discussions with parents}

FGDs were conducted with separate groups of mothers and fathers of at least one unmarried daughter aged 15-19 years to explore community and parental norms around child marriage. Specific topics included engagement and gauna ceremony (which is associated with consummation of marriage i.e. the marriage has occurred earlier, and cohabi- tation starts only after this ceremony, gender role attitudes, expectations from girls with regard to education, work, and marriage, and alternatives to early marriage. The FGDs also explored how parents understand legislation and policies related to child marriage. A total of 15 FGDs were conducted with parents across four states: 5 with groups of fathers (2 in Odisha and 1 in each of Bihar, Jharkhand, and Rajasthan) and 10 with groups of mothers ( 4 in Odisha and 2 in each of Bihar, Jharkhand, and Rajasthan).

\section{Data Analysis}

All FGDs were recorded and later transcribed verbatim before being translated into English. The lead researcher (KS) coded excerpts from the transcripts by theme and organized them in a codebook that was reviewed and refined in partnership with the wider research team. As analysis progressed, the team examined codes according to similarities and differences that emerged during analysis, sorting codes into categories and subcategories and collapsing or merging codes as needed. The final coding scheme is presented in Table 3. 
Table 1. Profile of adolescent girls aged 12-19 years in study sites by states, MTBA baseline survey, 2016

\begin{tabular}{|c|c|c|c|c|}
\hline & Bihar & Jharkhand & Odisha & Rajasthan \\
\hline$\%$ belonging to scheduled caste or tribe & 33.4 & 41.0 & 50.2 & 29.4 \\
\hline \% currently in school & 63.3 & 54.5 & 57.8 & 61.6 \\
\hline Median years of schooling & 6.0 & 8.0 & 8.0 & 8.0 \\
\hline Number of girls aged 12-19 & 754 & 731 & 721 & 776 \\
\hline$\%$ of girls aged $15-19$ years, working for pay & 29.9 & 35.5 & 48.1 & 26.2 \\
\hline $\begin{array}{l}\% \text { of girls aged } 15-19 \text { years, with any vocational } \\
\text { training }\end{array}$ & 12.3 & 10.7 & 6.3 & 4.4 \\
\hline Number of girls aged 15-19 & 365 & 382 & 430 & 451 \\
\hline $\begin{array}{l}\% \text { of girls aged } 12-19 \text { years, currently married and } \\
\text { living with husband }\end{array}$ & 13.4 & 26.4 & 7.5 & 7.5 \\
\hline $\begin{array}{l}\% \text { of girls aged } 12-19 \text { years, currently married } \\
\text { (including those for whom gauna not performed) }\end{array}$ & 16.6 & 26.7 & 7.5 & 22.9 \\
\hline Number of girls aged 12-19 & 754 & 731 & 721 & 776 \\
\hline Median age at marriage & 15.0 & 15.0 & 17.0 & 14.0 \\
\hline Number of girls who are currently married & 125 & 195 & 54 & 178 \\
\hline Median age at cohabitation & 15.0 & 15.0 & 17.0 & 17.0 \\
\hline $\begin{array}{l}\text { Number of girls who have started cohabiting with } \\
\text { husband }\end{array}$ & 101 & 193 & 54 & 58 \\
\hline$\%$ of girls aged $18-19$ years, married before age 18 & 50.0 & 63.0 & 15.0 & 42.0 \\
\hline Number of girls aged 18-19 & 117 & 139 & 165 & 135 \\
\hline
\end{tabular}

Table 2. Data collection methods used in the qualitative research

\begin{tabular}{|l|l|c|}
\hline Method/participant type & Participants in each group & Number of FGDs \\
\hline \multirow{3}{*}{ FGD with adolescent girls } & Unmarried girls aged 12-14 & $1(\mathrm{Rj})+1(\mathrm{Bh})+1(\mathrm{Jh})+2(\mathrm{Od})=5$ \\
\cline { 2 - 3 } & Unmarried girls aged 15-19 & $1(\mathrm{Rj})+1(\mathrm{Bh})+1(\mathrm{Jh})+2(\mathrm{Od})=5$ \\
\cline { 2 - 3 } & Married girls aged $12-19$ & $1(\mathrm{Rj})+1(\mathrm{Bh})+2(\mathrm{Od})=4$ \\
\hline \multirow{2}{*}{ FGD with parents } & Fathers of unmarried girls aged $15-19$ & $1(\mathrm{Rj})+1(\mathrm{Bh})+1(\mathrm{Jh})+2(\mathrm{Od})=5$ \\
\cline { 2 - 3 } & Mothers of unmarried girls aged $15-19$ & $2(\mathrm{Rj})+2(\mathrm{Bh})+2(\mathrm{Jh})+4(\mathrm{Od})=10$ \\
\hline
\end{tabular}

$\mathrm{Rj}=$ Rajasthan. $\mathrm{Bh}=$ Bihar. $\mathrm{Jh}=$ Jharkhand. Od = Odisha. 
Table 3. Main themes and subthemes addressed in qualitative data

\begin{tabular}{|c|c|c|c|}
\hline Main themes & Subthemes & Girls & Parents \\
\hline Adolescent girls' profile & & $\checkmark$ & \\
\hline \multirow{2}{*}{ Social assets } & Friends and interactions & $\checkmark$ & \\
\hline & Confidants for health problems & $\checkmark$ & \\
\hline \multirow{4}{*}{ Human assets } & Education & $\checkmark$ & $\checkmark$ \\
\hline & Livelihoods & $\checkmark$ & $\checkmark$ \\
\hline & Freedom of movement & $\checkmark$ & $\checkmark$ \\
\hline & Safe spaces & $\checkmark$ & $\checkmark$ \\
\hline \multirow{3}{*}{$\begin{array}{l}\text { Access to educational and } \\
\text { livelihood } \\
\text { opportunities, girls' value }\end{array}$} & Access to educational opportunities & & $\checkmark$ \\
\hline & Access to livelihood opportunities & & $\checkmark$ \\
\hline & Expectation from daughters & & $\checkmark$ \\
\hline \multirow[t]{2}{*}{ Girls' agency } & Safety issues and safe spaces & $\checkmark$ & $\checkmark$ \\
\hline & Mobility & $\checkmark$ & $\checkmark$ \\
\hline \multirow{5}{*}{$\begin{array}{l}\text { Parental preference and } \\
\text { community } \\
\text { perception around marriage } \\
\text { age }\end{array}$} & $\begin{array}{l}\text { Preferred age for having daughters } \\
\text { marry }\end{array}$ & & $\checkmark$ \\
\hline & Reasons for marriage before age 18 & & $\checkmark$ \\
\hline & Reasons for marriage after age 18 & & $\checkmark$ \\
\hline & $\begin{array}{l}\text { Consequences of marrying after } \\
\text { age } 18\end{array}$ & & $\checkmark$ \\
\hline & $\begin{array}{l}\text { Community response to child mar- } \\
\text { riage }\end{array}$ & & $\checkmark$ \\
\hline $\begin{array}{l}\text { Alternative to } \\
\text { marriage }\end{array}$ & & $\checkmark$ & $\checkmark$ \\
\hline \multirow{5}{*}{$\begin{array}{l}\text { Awareness about laws and } \\
\text { acts for prevention of early } \\
\text { marriage }\end{array}$} & Awareness of child-marriage age law & & $\checkmark$ \\
\hline & $\begin{array}{l}\text { Awareness of marriage registration } \\
\text { act and dowry act }\end{array}$ & & $\checkmark$ \\
\hline & $\begin{array}{l}\text { Help-seeking behavior from child } \\
\text { protection groups }\end{array}$ & $\checkmark$ & \\
\hline & $\begin{array}{l}\text { Enforcement of law/perception of } \\
\text { law }\end{array}$ & & $\checkmark$ \\
\hline & Examples of enforcement of law & & $\checkmark$ \\
\hline
\end{tabular}


Results

Awareness and Enforcement of Legal

Restrictions on Age at Marriage

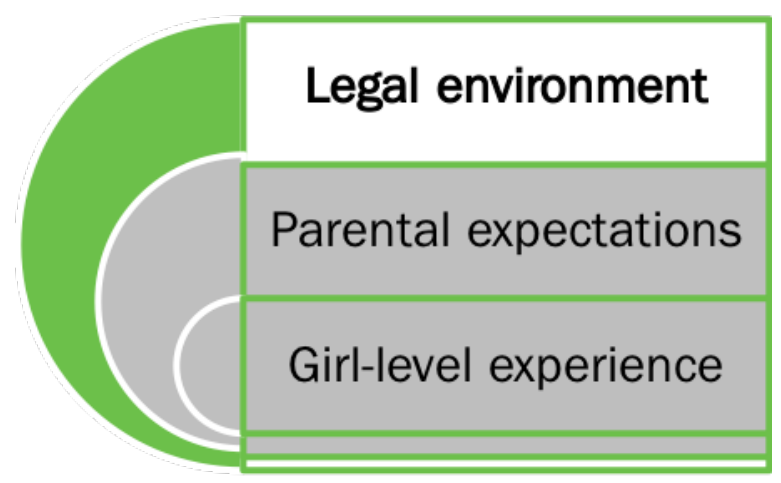

Raising awareness and increasing enforcement of child marriage laws is one strategy for reducing early marriages. The Girls Not Brides partnership, global leaders in raising advocacy for reducing child marriage, develops and implements laws and policies as one of four pillars in their theory of change (Girls Not Brides 2018). In India, laws prohibiting child marriage already exist, so programs focusing on child marriage may work on raising awareness and increasing enforcement of these laws rather than on advocating for new laws. Additional laws not included here may also influence child marriage less directly. For example, although the Child Marriage Act (2006) addressed the issue of child marriage more broadly, it did not address sex with minor brides. Recently, Section 375 of the Indian Penal Code (IPC) prescribed the age of consent for sexual intercourse as 18 years, implying that any person having sexual intercourse with a girl child-including married girls under the age of 18-would be guilty of rape, even if the sexual activity was with the girl's consent.

We were interested to learn about awareness of these laws and about how the enforcement is carried out and/or perceived at the community level. We found that both knowledge and awareness of the laws were mixed, but among those who were aware of laws against early marriage, perceptions of punishment for violating the law were severe.

Mothers in Odisha reported some understanding of the Child Marriage Act and the "government people" who are advocating for a later age at marriage for girls:

\section{Legal Framework Influencing Child Marriage in India}

- $\quad$ Prohibition of Child Marriage Act (2006) establishes 18 as the legal age of marriage for females and stipulates punishments for violations.

- $\quad$ Compulsory Registration of Marriage Bill (2013) requires all marriages to be registered.

- Dowry Prohibition Act (1961) prohibits the payment of dowry at marriage.

I: What else have you heard about the child marriage act?

R9: There is a labor card. The girls should marry at the age of 20. That is written on that card.

I: Is that written on the card?

R9: The government people are telling about that.

-Mother in Odisha

In Rajasthan, some mothers reported not being aware of any laws or government attempts to delay marriage while others were aware, suggesting that efforts to disseminate this information have not been universally effective.

R1: We have not heard about this. We do not conduct marriages among minors by ourselves, but we did not hear about any law. We do not know what law the government made.

R2: Government says that girls' marriage should not take place at a minor age, it should only take place after 18 years.

R3: We heard that if some girl is married as a minor, police arrest him, they do not let the marriage occur.

R2: They arrest and take them and they hurt them after bringing them there. They do not release them from prison for many days.

-Mothers in Rajasthan 
Fathers in Bihar reported mixed knowledge of the laws, but they also acknowledged that the threat of punishment did not deter them in making decisions about what was best for their daughters:

R2: We have the knowledge.

R1: Yes, we have [the knowledge] but nobody follows the laws.

I: What will happen if someone marries before 18 years of age? What is there in that law?

R3: The thing is that nobody knows about this law.

R4: We don't have the knowledge.

R1: The parents will be imprisoned, means there are many inconveniences, but the people don't accept it.

-Fathers in Bihar

Unmarried girls in Bihar were aware of the laws and associated harsh punishments with breaking the law. They spoke of "everyone" associated with the marriage being in trouble if a girl is underage:

R7: All the people including the people who came to the wedding, the cook, the workers, their neighbors all are imprisoned and have to pay the fine.

R12: They will be imprisoned for two years and all the members of the family and all those who were present at the wedding will also be imprisoned.

R2: The mediator will also be punished.

R4: All will be imprisoned.

R4: The priest who conducts the marriage and even the person who plays the drums will be punished. The people who attend the wedding will also be punished.

-Unmarried girls in Bihar

In addition to the Child Marriage Act, we asked about the Marriage Registration Act and found that almost none of the respondents had awareness of it. Many reported that marriages are not being registered in their communities, such as this mother from Jharkhand:

[Marriage registration] has not happened yet. We have done so many marriages but we have not seen anything like this ever.

-Mother in Jharkhand

We also asked about the Dowry Prohibition Act, which forbids the payment of dowry at marriage, and found that there was greater knowledge of this law but limited enforcement. One mother in Jharkhand noted:

It's a crime to give and take dowry. But people don't follow it. If I have a daughter then I will have to give dowry.

-Mother in Jharkhand

Similarly, a mother in Bihar reported:

Everyone knows about that [Dowry Prohibition Act], but those who want the dowry will take it and those who don't want it they don't take it. Some take less and some take more.

-Mother in Bihar

Some mothers in Rajasthan did not believe there is a law regarding dowry that applied to their community:

Here there isn't any law not to give the dowry. Nobody is told not to give the dowry. And not even any boy's family asked for the dowry; we give it with our choice and nobody has said that you are poor so don't give any dowry. We have to give the dowry.

-Mother in Rajasthan

Some mothers who were aware of the Dowry Prohibition Act acknowledged that dowry occurred, but that enforcement of the law was only used when boys' families asked for too much:

R3: They have made that law. Because of that [law] the government punishes [people who do not follow]. If people ask for more dowry, then we can complain and then they will be punished.

R2: If a highly educated boy is there, then they ask for dowry.

R3: A highly educated boy will ask for a car or motorcycle, then they catch them.

-Mothers in Rajasthan

We asked respondents if they had knowledge of anyone being punished for breaking laws related to early marriage. Mothers in Jharkhand relayed a story that occurred in a nearby village:

R9: Yes, it has happened in another village. It has not happened in our village.

R9: They caught them, took them, and then kept them in lockup. It means they were locked in the jail. What else will happen? If they marry before 18 years of age 
then that law will only be imposed. He married a girl at the age of 12 years and that's why he was arrested.

R9: They caught the girl and took her, they have kept her in jail. They will keep the boy also in the jail, what else will they do.

R2: And they keep their guardian also in the jail.

-Mothers in Jharkhand

Mothers in Jharkhand also reported that this happens in other communities but not in their own, possibly suggesting differences in marriage practices or acceptance of marriage laws among different groups:

R3: It happens in the "gwala" community. These people know about it.

R7: It happens in the "gwala" community and here no gwala lives.

R2: We belong to "baniya" community and we don't do it.

-Mothers in Jharkhand

\section{Parental Expectations}

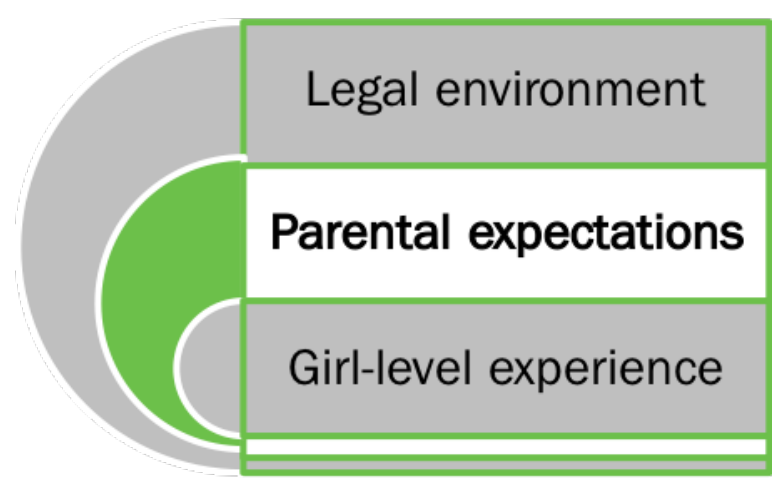

\section{Education}

We know from previous research that marriage often marks the end of formal schooling for girls. In the baseline report (Basu et al. 2017) we found that most unmarried girls reported being in school, while married girls were mostly out of school. We found that the median years of schooling for girls aged 12-19 was 8.0 in Jharkhand, Odisha, and Rajasthan, and 6.0 in Bihar. In the baseline study we also asked girls about reasons for leaving school. Among the most common reasons were housework-related, negative perceptions about education for girls, economic reasons, followed by school-related reasons (such as distance to school).

\section{POVERTY AND EDUCATION}

We are farmer people and cannot afford girls' further education. Those who are rich, only their daughters study further. People who are poor and dependent on farming, their girls are able to study until there is [no longer] a school in the village.

-Father in Rajasthan

In the qualitative research, we asked parents about education for their daughters to understand how expectations for daughters' schooling influence marital timing and school discontinuation. In contrast to what girls told us in the baseline report, we found that parents put a greater emphasis on economic and school-related reasons for discontinuing girls' education, and less emphasis on household-related reasons and gender attitudes related to girls' education.

Fathers in Rajasthan noted that schooling is limited for girls because they are unable to leave their villages to further their studies due to both economic and safety concerns. Therefore, education ends once girls have completed the education available to them in their villages:

How they will complete their education? There is only a school up to Class 8 in this village. We do not give them education after Class 8. We do not send them far away for studies.

-Father in Rajasthan

Fathers also acknowledged the gender differences in decision-making regarding schooling for their children. In families with limited resources, education for boys is seen as a better long-term investment, as girls will leave their natal homes once married:

If there are 3 to 5 boys and girls in a family, then people consider who to teach and who to not. Today girls are living in our home, but after marriage they will go to another house and will not live with us. It is okay whatever they have studied since, after marriage, they will give their earnings to the in-laws' family and not to their parents. This is also one of the reasons for not thinking about girls' higher studies.

-Father in Rajasthan 
Mothers in Rajasthan echoed that the reasons girls end their education at Class 8 are primarily economic:

R7: People do not get their daughters education in private school because of money problems and government schools are so far from the village. This is the problem in our village.

R1: For further studies they have to go to [larger village].

R2: My daughter got education until Class 5 and then there was not any school nearby so that is why she left.

-Mothers in Rajasthan

Sending girls for further education outside the village requires the means to do so and raises questions of security, as one mother worries that girls may "run away with boys":

R4: School is not nearby and if we would get them education in private schools, so it takes more money and we do not have money.

R7: There is school only up to Class 5 in nearby village and now where would we send girls for further studies. Who will go with the girls?

R7: Girls run away with boys.

R4: They do not run away. Parents do not have money, that is why they do not get them education.

-Mothers in Rajasthan

Fathers in Bihar cited the nature of their work and economic uncertainty as major factors driving the termination of their daughters' educations:

R3: We all are farmers and many face unfavorable situations, so they are not able to study further.

R5: Here men are laborers, farmers, are poor. They are not able to spend that much money.

R2: Because of money some are able to study, and some are not.

R2: We are poor people. And we don't have facilities to go to and fro, and then what can we do?

-Fathers in Bihar

Parents also complained about the quality of the teaching in schools, so that even when girls do attend schools up to the highest available levels, parents are concerned about the quality of the teaching:

\section{QUALITY OF EDUCATION}

The teachers don't teach the students in the school. If the teacher will teach, only then the students will learn.

-Mothers in Rajasthan

\section{HARRASSMENT}

When a girl goes to the school or when a group of girls go, then the boys come and ask them to go with them and ask them who will go with them. Because of this, the girls are afraid to go to the school, so they don't go.

-Mother in Bihar

R4: Sometimes they take the class in the school and sometimes they don't. The teachers don't teach the students in the school. If the teacher will teach, only then the students will learn.

R2: My daughter is also studying; she goes to the school in [location]. She is in 10th standard now but she is gaining little knowledge.

R6: If they keep the students busy, then the students will not go out of the school. If the teachers don't concentrate on the students and do their own work, then the students will roam around.

R2: The teachers don't teach our daughter also in the school. The teachers are somewhere else, and the girls are somewhere else.

-Mothers in Rajasthan

Mothers in Jharkhand report that the lack of educational opportunities extends beyond formal school infrastructure, to informal educational structures and vocational training programs for girls as well, making it difficult for girls to learn skills that may be useful for earning income:

R6: Although all girls want to study, learn stitching, computer, typing, etc., there are no such facilities available in the village. All these things should be available in the village.

R3: What can we say as nothing is available here.

-Mothers in Jharkhand 
In addition to a lack of opportunity for girls to continue their studies, there are also security risks as perceived by parents. Concerns about safety seem to be multifaceted, including concerns related to bodily harm. In recent years, India has had a number of high-profile incidents of extreme violence against young women (Narayan 2018) that may influence parental concerns about girls' safety in their communities. As mothers in Bihar say, there are concerns for girls' safety when they go to study:

R5: They are not able to do. The only reason for that if they go out to study then the boys will follow them. They do anything, they can do anything, they can even hold them, and they can beat them. This is the reason that we are not able to send our girls there to study.

R8: Even if any other girl is with them, then also when the boys see the girls they follow them. That is the reason that they don't go, they remain at the house and study.

R5: When the girls go to study, then the boys come, follow them, and disturb them. Because of this reason all the girls get afraid that when they go to study all these things happen. They come and tell their mothers about this and say that they will not go to study in the future. So they remain at home and study, they say that they want to remain in the village.

-Mothers in Bihar

As the above quotes demonstrate, mothers suggest that both parents and girls themselves believe it is better for girls to avoid going out to study because of unwanted attention and harassment from boys, so they remain at home and in their villages rather than travel for educational purposes. In the same FGD in Bihar, mothers noted that this type of unwanted attention may lead to girls being taken away from their village:

R8: When a girl goes to the school or when a group of girls go, then the boys come and ask them to go with them and ask them who will go with them. Because of this, the girls are afraid to go to the school so they don't go.

I: Did anything like this happen recently?

R4: Yes, it has happened; three to four times it has happened.

R10: The boy ran after taking the girl of another village. The boys take the girls and run away.

R8: And he was from another village. He took the girl and ran off.
I: Is this the reason that you don't want to send the girls out?

R7: This is the reason that we don't send our girls.

R5: The girls are also afraid.

-Mothers in Bihar

\section{Livelihoods}

One key component of the MTBA approach is expanding opportunities for girls by increasing access to alternatives to early marriage. Livelihood opportunities are an important alternative to marriage. In our baseline report we found that among adolescents aged 15-19, participation in wage work (either in the form of cash or kind) was highest in Odisha (48 percent) and lowest in Rajasthan (26 percent). The majority of those working for wages during the last month were engaged in farm or agricultural labor (25 percent and 38 percent in Odisha and Bihar, respectively, and 53 percent and 60 percent in Jharkhand and Rajasthan, respectively).

In Bihar, mothers discussed how girls mostly work in agriculture, but that this work was not completed for money but rather to fulfill family obligation:

No, they don't earn money. She goes with her parents to their farm. She goes with them to others' farms if there is extra work in the farm then she does that, she also goes to her own farm. She goes to do the same work. She goes there to help them.

-Mother in Bihar

Despite finding in our baseline study that more girls were engaged in paid work in Odisha compared to other study areas, mothers there focused on the domestic responsibilities of girls when asked about what girls do for work in their communities:

R5: They are studying, they tutor the children.

R2: They tutor the children. Tailoring.

R1: They are cooking. They marry before 18 years and what else do they do.

R10: Tailoring, cooking.

-Mothers in Odisha

In Jharkhand, parents told us about paid work opportunities for girls, which were mostly manual labor. Mothers in Jharkhand explained that poverty means few girls can study and instead must work, noting that girls participate in labor 
work, including working on farms, carrying loads, and working in brick kilns:

R6: They work in brick kiln.

R9: They make "bidi," carry bricks, and do labor work.

R9: People here do labor work. They have four or five daughters, so they cannot afford education for all. There is only one earning member and five to six members depend on him. So how much can he afford?

R8: This is the main problem, and this is same for all of us. They all carry loads. First, they do labor work and look after a family of five to six members. I also have three daughters. And there is only one person who earns. So, what we can do? Nothing is being given by the school like money, cycle, or anything else. They would have gone if they had got something.

R2: They do labor work only.

R5: My daughter is working in the farms.

-Mothers in Jharkhand

Fathers noted that there are few opportunities for girls in Jharkhand because there are few types of jobs broadly speaking in their communities:

I: What kind of work do girls do?

R4: Like paddy plantation, harvesting of paddy, etc. They do all these things.

R2: They also move the bricks. Girls who are poor go to move the bricks.

R7: They do wage kind of works.

R6: Here there are no resources. Only this work is here.

R8: There is not any plant or factory, so no one works in factory here.

R1: Here there is not any sewing work, etc.

-Fathers in Jharkhand

Fathers in Bihar reported that girls do not typically work outside the home; instead girls have many domestic responsibilities to attend to. Interestingly, fathers noted that their duties toward household chores and working for their own farm is more important than working outside the home and they acknowledged that girls usually "don't go outside":

R2: They work at home.

R6: Yes, they do cooking and stay at home.
R2: Stitching their clothes or knit something with wool.

R1: They work at home. Cooking or washing, what else can they do?

R8: They don't go outside.

R4: No, they don't go outside.

R5: No, they don't work in the fields.

R7: They just ramble around in the fields, but don't work there.

R6: They will do only whatever work is there in the home.

-Fathers in Bihar

Similarly, fathers in Rajasthan also reported that girls usually don't go outside and prefer to work for their home and do domestic duties:

\section{R1: They work in farm or work at home.}

R4: Does work at home, and if there is a farming work in the house, then they do that, and also do work of cattle rearing, such as goat or buffalo.

R3: Some girls also go for wages. If there is no work of wages in the house, then they go out for work, otherwise how they will pass their time.

-Fathers in Rajasthan

One mother from Jharkhand spoke about the difficulty in wanting to provide monetary support for her daughter, but because of their poverty, she must allow her daughter to work and earn:

We are poor so we don't have money. My daughter asks for money. Then I'm told that we don't have money so how do we give. Then she said okay, then I will go to lift bricks.

-Mother in Jharkhand

\section{Parental Perceptions of Mobility}

We asked parents about girls' mobility to better understand when and where they are allowed to move freely in their communities. Mothers in Bihar reported that few girls were allowed to go out alone. However, as noted in this group discussion, within the village, girls were given much more freedom in their movements:

R8: Without their guardian, the girls don't go out. Here there isn't any girl who goes out alone. 
R6: Not even a single girl goes out without her guardian. When she goes out, then she always goes with her guardian.

R8: She can roam around in the village.

R2: Yes, she can be in the village.

R8: She can roam around in the village; what is there in the village?

R6: We know where they go.

R7: In her village she can go anywhere.

-Mothers in Bihar

Similarly, in Rajasthan, girls' movements were restricted except in the village where mothers did not worry too much about girls since they perceived few risks present there:

R3: They don't go anywhere else [besides the village]. We don't send the girls anywhere alone.

R4: They can go anywhere inside the village.

R5: They go to fetch water, they go to the farm, and they come to the house.

R6: Other than this, they don't go anywhere else.

-Mothers in Rajasthan

Fathers perceived girls to have freedom of movement within the village as well, noting some restrictions based on distance from the village center:

R6: Yes, they can go out [alone]. There is no problem in that.

R4: Like there is no resource of water, so there is a hand pump at the edge of road so they can go there.

R8: Yes, within a half-kilometer of the circle.

R10: This is small village. This is not a big village. This is a small village, that is why they go out. There is not any problem.

-Fathers in Jharkhand

Fathers in Odisha noted that unless there is a reason for girls to go outside, like an opportunity to work, there is no reason for them to be outside the home:

R8: As there is no work available, why [should] girls go outside?

R4: They are going to their auntie's home if there is some work.

R8: If there is work or a company will come, then they will go. Otherwise why should they go?
R4: They are not even going outside of the home. Why?

R3: There are no facilities.

R2: And they are also very young.

R8: They are not earning money. They are not going anywhere for work.

R8: As there is not work available, they are not going. They are going to school, or to learn computer. And after coming [home], they are only sitting at home.

-Fathers in Odisha

We also asked parents about what spaces they consider to be safe for girls. Fathers in Rajasthan worried about sexual security for their daughters in certain areas:

R2: The thing is that people do not keep their thinking right; they look at the girl from dirty eyes/bad intentions.

R3: People cannot be trusted.

R4: Their thinking is dirty, and [they] do not consider the sister to be sister. They can do anything with girls.

I: What can they do?

R6: They can misbehave.

-Fathers in Rajasthan

Mothers in Odisha reported worrying about leaving their girls alone because of the situation "nowadays" and threats to their safety:

I will not leave my daughter alone. You know what is happening nowadays.

-Mother in Odisha

Some mothers spoke about certain places being safe if their daughters behaved appropriately, especially regarding boys. Mothers in Jharkhand spoke of how encouraging boys could lead to the risk of being taken away:

R3: All the places are safe. But if you touch a boy or signal him, then he will take you and run away. That is the matter. Otherwise all the places are safe for us. Nobody is able to touch us. If you touch, then he will take you and run away.

R9: Right, if the girl is correct then the boy won't take her and run away.

-Mothers in Jharkhand 
Parents' safety concerns also included fears related to sexual security, as even nonconsensual premarital sexual relations can have a negative influence on a girl's reputation. These mothers explained how contact with a boy may spoil a girl's honor, and therefore her family's reputation and her marital prospects:

I: So, what is the fear?

R1: Prestige.

I: You have fear about prestige.

R3: Even if they don't study, it is fine. At least they will stay at home. Whatever problem happens is fine. She will stay at home only. What to do?

R5: It is about prestige, what else. It is about the girl.

R6: If boys catch them they may spoil the prestige.

R10: That's why everybody is scared.

-Mothers in Jharkhand

Concerns about sexual security were related to girls' immediate safety and to their future marriage prospects. Mothers in Rajasthan, explained:

R4: If anything wrong happens to the girl, then nobody is ready to marry that girl.

R5: If anyone makes any kind of relationship with her, then nobody will want to marry her.

R6: Then where will the girl go, if anything like this happens?

-Mothers in Rajasthan

\section{Gender Roles and Expectations}

There is little incentive for parents to educate their daughters when expectations center on girls' roles within the home and strong gender norms emphasize daughters' caretaking responsibilities. As a mother in Rajasthan explained:

Yes, a daughter will serve us. When a daughter would go to her in-laws, or would come to her parents' house so she will help her mother. A son does not help us and he tells to his sister that she is your mother so you serve her.

-Mother in Rajasthan

However, there were some discrepancies within groups as one group of mothers from Rajasthan shows. In this focus group, taking care of parents also extends to earning a living to "move forward" and make parents proud:
R1: What kind of expectations do we have for our daughters? We only expect from them that when they go to their in-laws they make their parents name shine. We expect them to live with their in-laws nicely and don't fight with anyone and spend their life with their husband nicely.

R3: We expect our daughters to study well and get a good job. We want them to move forward and make us proud.

R4: They cannot make us proud by studying less and they will not get a good job.

R7: If she makes her husband happy, then her husband will also keep her happy otherwise he will beat her and leave her.

R3: We want our daughters to study until they want to.

R6: Like we educate our sons the same way, we expect our daughters to study and become capable.

-Mothers in Rajasthan

In Odisha, fathers reported expectations that their daughters will earn money. The pressure for a daughter to earn money was especially high in situations where fathers did not have sons:

R3: They should study like sons. They should give some money by earning. This is the expectation.

R4: Those parents who don't have sons will definitely expect things from daughters. Our daughter will earn some money like our son.

R3: We don't want to take our daughter's responsibility; she should stand on her own. They are expecting this.

R4: I am saying children should learn to get a job and give me some money. As I don't have a son I will just sit and eat.

R2: They will give some money at home by earning. They will earn and save some money for their own marriage.

-Fathers in Odisha

\section{Perceptions about Preferred Age at Marriage}

We asked mothers and fathers about the ideal marriage age for their daughters, what made this the age ideal, and markers for readiness.

Mothers in Rajasthan gave differing opinions on the ideal age. While some thought girls were mature enough at 15 


\section{REASONS GIVEN FOR WHY PARENTS MARRY GIRLS EARLY}

Financial burden of caring for the girl (education as well as basic needs).

Concerns about her value on the marriage market related to:

- Sexual security and honor.

- $\quad$ Gossip from others if a daughter is not married by a certain age.

- Social norms about early marriage.

or 16 years of age, others suggested that after age 18 was ideal. Still some answered without giving a particular age, rather referencing a girl's maturity or the end of her schooling as important markers of marriage readiness:

R1: At 15-16 years we think that they are mature enough for the marriage.

R3: When she becomes a little big [physically mature], then we start thinking of her marriage.

R1: Nowadays we do the marriage after 18-19 years of age.

R3: Earlier we used to do the marriage of our daughters when they were so small that they were in our hands only.

R5: As the girls become big [physically mature] they become a burden for their parents. They think that now since she is not studying they [should] do their marriage. And then they start saving money for marriage.

-Mothers in Rajasthan

Some fathers spoke of changes over time with respect to age at marriage. As one father in Bihar said:

Now, slowly, everyone is getting educated and plan to conduct [marriages] at 17-18 years of age.

-Father from Bihar

Some mothers noted that if there is not an alternative to marriage like studying, there is little reason to delay her marriage:

If there isn't any other facility to study or to learn stitching, then how will we keep our girl unmarried?

-Mother from Bihar

\section{CONCERNS ABOUT SAFETY}

Maybe she gets spoiled or maybe she gets pregnant or maybe she gets molested by someone. Due to this fear, we marry her early.

-Mother in Jharkhand

However, even if age at marriage is being delayed, parents report that they start to think about and plan for their daughters' marriage far earlier. Both mothers and fathers in Bihar reported that planning for their daughters' marriage began at 14-15:

Well, by the age of 14-15 years we start thinking about financial expenses, what will we gift our daughter, how much amount has to be given, what will be the problem, what we will give. Then, beforehand, we have to make arrangements for the same.

-Father from Bihar

Yes, at 14-15 years we start thinking about the marriage of our daughters. There isn't any educational facility for the girls here. So we make them marry.

-Mother from Bihar

We asked parents about the reasons why girls are married under age 18 in their communities. Parents reported that economic concerns, including an inability to pay for further education, were an important consideration. As one mother from Odisha stated:

We have to spend money-up to 4 to 5 thousand-for a child to study more. Those parents who have 3 to 4 children how will they manage? So, we marry our daughters early.

-Mother from Odisha

One father from Jharkhand spoke of the financial burden of caring for his daughter and how things in the village may be different from more urban areas:

It gets difficult for us to keep her. This is not a city or town. This is village area. They think about early marriage. If she turned 18 her marriage must take place.

-Father from Jharkhand

Other parents spoke of concerns including concerns about girls' safety, girls' sexual security, and marriage prospects. A mother from Jharkhand put it this way: 
That's why we marry them at an early age, due to the fear of getting defamed. What we can do? By the age of 12-13 years we get interest in the girl. We could make a mistake and things [could] get messed up. That's why we marry them soon. Maybe she gets spoiled or maybe she gets pregnant or maybe she gets molested by someone. Due to this fear, we marry her early.

-Mother in Jharkhand

Mothers from Odisha demonstrated differing opinions, weighing the risks of marrying girls young with the perceived consequences of waiting too long to have their daughters married:

R3: If the girl will marry in early age that is not good.

R2: Nowadays, if our daughter will not marry [until] up to 19-20 years the villagers will gossip with each other that her daughter is not marrying.

R2: If the daughter will marry in the early age then she and her child will be weak and may die also, so we are marrying our girls in 18-20 years of age.

-Mothers in Odisha

Parents also cited other reasons for delaying girls' marriage until after age 18. Many cited education as an acceptable reason to delay marriage. Others spoke of the influence of various pressures to delay marriage, including pressure from government officials. One mother from Bihar noted that delaying marriage until after 18 is necessary to avoid problems:

After 18 years only the marriages are conducted. Nitish Kumar [Chief Minister of Bihar] said that after 18 years only marriages should be done. Now if we conduct the marriages in between, then it will cause problem to us only.

-Mother in Bihar

Other mothers reported delaying marriage because of financial pressures and the influence of gauna. Mothers in Rajasthan suggested that lack of money was a driving factor for later marriage:

R4: We do not have money, that is why we do marriage after old age. People who have money they even do at minor age.

R6: No one does marriage at minor age nowadays. People have to spend more money by doing marriage at minor age because people have to give a lot to her in-law till doing gauna and it takes a lot of money so that is why people do marriage only after 18.

\section{PARENTS' REASONS FOR NOT MARRYING GIRLS EARLY}

Concerns about her health if she has a child too young.

Economic costs of marriage, including high costs of gauna if she is promised too young.

Influence of laws/input from government officials about what is appropriate.

R7: When they do marriage at old age so they do gauna too at that same time.

-Mothers in Rajasthan

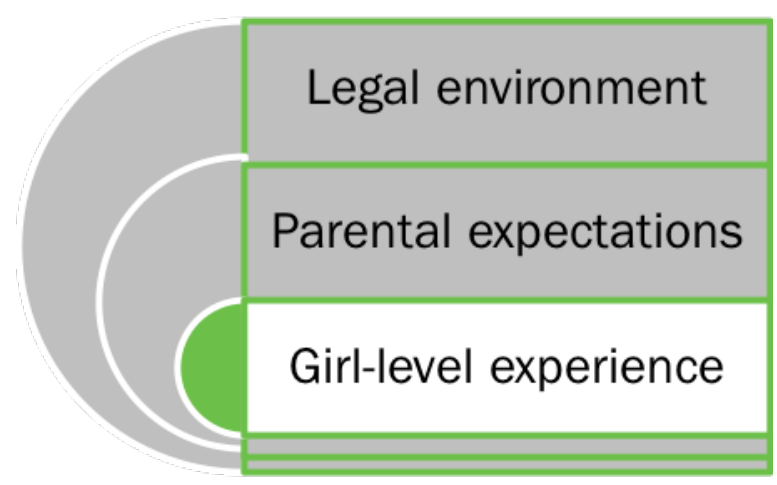

\section{Girls' Experience}

\section{Profile of Adolescent Girls}

Drawing on data from the FGDs conducted with adolescent girls (groups of 12-14-year-olds and groups of 15-19-yearolds), we present a profile of the lives of adolescent girls in the study settings. In describing the situation of adolescent girls, we focus on the extent to which girls have acquired assets that might help to protect them from conditions leading to early marriage.

\section{Peer Interactions}

We know from previous research that social isolation is related to a number of negative outcomes for girls including sexual violence, early sexual initiation, and increased HIV risk (Erulkar and Mekbib 2007; Erulkar and Ferede 2009). To understand girls' social networks and whether these networks may be protective against child marriage or the negative effects associated with child marriage, we explored how adolescent girls engage with one another and how interaction may differ by age and/or marital status. We 
asked girls about what they do with their friends and what they talk about. Girls discussed a range of activities and conversation topics. Among younger, unmarried girls, many still reported playing with their friends:

R3: We play, we talk about what are you doing today.... We ask about the mother, how she is, do you have some work to do, how he is, and you tell. We talk about school-what was going on in school today, etc.

R4: If any girl does not go to school so we ask her about it.

R5: Yes, like we had gone to play here so someone had a fight there, so we tell her about it.

R8: And if a new girl would have come in the school, so I tell her about it.

R9: We play.

R10: We worship in temple.

-Unmarried girls, aged 12-14, Rajasthan

Older unmarried girls reported discussing their lives and problems with their friends and providing one another with encouragement and support. One group of unmarried girls aged 15-19 reported that they share problems and talk about their future marriages with their friends:

R1: We talk to each other. We ask each other about their wellness.

R1: And whenever there is any problem, then we share that to our friends. We tell them what all happened, then they also share their problems with us.

R2: If we are not able to understand what we are studying then we clear each other's doubts. We take our friend's help.

R3: Problems are solved.

R4: We even crack jokes.

R5: We do our studies. We can tell them where we reached, and we can clear their doubts, and they can clear our doubts.

R6: We play, other than this we meet and laugh together.

R7: We even learn to stitch together.

R8: We talk about marriages.

R2: We learn to dance and sing.

-Unmarried girls, aged 15-19, Bihar

\section{IMPORTANCE OF FRIEND GROUPS}

Sometimes we sit and talk too much. We even talk important things about anything that happened. There are many things that we talk about and get information, like this we live together.

-Unmarried girl, Jharkhand

These relationships appear to be important for information sharing. Among unmarried girls in Jharkhand, girls reported that their friend groups were sources of information and a network to consult on decisions, including questions related to education:

R1: We consult them about education. We ask each other, what have they studied, will they go to school or not, etc.

R3: We ask our friends about the time spend by them in studies. We talk about all this.

R7: Sometimes we sit and talk too much. We even talk important things about anything that happened. There are many things that we talk about and get information, like this we live together.

-Unmarried girls, aged 15-19, Jharkhand

These relationships appear to be important for information sharing. Among unmarried girls in Jharkhand, girls reported that their friend groups were sources of information and a network to consult on decisions, including questions related to education:

R1: We consult them about education. We ask each other, what have they studied, will they go to school or not, etc.

R3: We ask our friends about the time spend by them in studies. We talk about all this.

R7: Sometimes we sit and talk too much. We even talk important things about anything that happened. There are many things that we talk about and get information, like this we live together.

-Unmarried girls, aged 15-19, Jharkhand

Social connections and friendships were also reported among married girls. Married girls described how they continue to rely on and confide in one another. They also reported going to one another for help with tasks such as stitching, suggesting that these relationships are beneficial 
Table 4. Main sources of information and services for SRHR concerns

\begin{tabular}{|l|l|l|l|l|}
\hline & \multicolumn{2}{|c|}{ Unmarried girls aged 15-19 } & \multicolumn{2}{c|}{ Married girls aged 12-19 } \\
\hline Topic discussed & $\begin{array}{l}\text { Main sources of } \\
\text { information }\end{array}$ & $\begin{array}{l}\text { Reported source } \\
\text { from where help can } \\
\text { be sought }\end{array}$ & $\begin{array}{l}\text { Main sources of } \\
\text { information }\end{array}$ & $\begin{array}{l}\text { Reported source from } \\
\text { where help can be } \\
\text { sought }\end{array}$ \\
\hline $\begin{array}{l}\text { Menstruation (unmar- } \\
\text { ried)/ Pregnancy related } \\
\text { and contraception } \\
\text { (married) }\end{array}$ & $\begin{array}{l}\text { Female family } \\
\text { members: Mothers, } \\
\text { sisters, female } \\
\text { friends; } \\
\text { School curriculum }\end{array}$ & $\begin{array}{l}\text { Private hospital, } \\
\text { medical stores, } \\
\text { ASHA }\end{array}$ & $\begin{array}{l}\text { Female family members: } \\
\text { Mothers/ mothers-in-law, } \\
\text { sisters, ASHA, Anganwadi } \\
\text { workers (AWW) }\end{array}$ & $\begin{array}{l}\text { Government hospital, } \\
\text { ASHA }\end{array}$ \\
\hline $\begin{array}{l}\text { Sexually transmitted } \\
\text { infections }\end{array}$ & $\begin{array}{l}\text { Female family } \\
\text { members }\end{array}$ & $\begin{array}{l}\text { Private doctors, } \\
\text { medical stores }\end{array}$ & $\begin{array}{l}\text { Female family members, } \\
\text { ASHA }\end{array}$ & Private doctors, ASHA \\
\hline
\end{tabular}

not only for social capital and connectedness, but also for building practical skills needed in their marital lives:

R2: What we do...we talk about studies, about in-laws, and also about native place.

R1: We talk about our mothers, sisters, and also do gossip about other friends.

R4: Like if we are unable to do something, then we take help from our friends. And if we have some work from some far place, then we ask our friend to go there and do that work for us.

If we face some difficulty in studies, then we take help from our friend.

-Married girls, aged 12-19, Bihar

Respondents indicated that they also share information about marriage with their friends. As one married girl in Odisha said, girls ask one another about marriage and husbands:

R3: We discuss about their families.

R6: We discuss about our family, children, husband, and mother-in-law.... Those who have done love marriage, we ask them about her husband.

R1: Those [that] are living happily, they will tell about their happy life. Those who are in jeopardy, they will tell about their unhappy life.

-Married girls, aged 15-19, Odisha

\section{Sexual and Reproductive Health Related Knowledge}

One important tenet in the MTBA theory of change is the availability and accessibility of sexual and reproductive health services. To better understand how girls learn about sexual and reproductive health services, we asked about sources of information, where they go if they have a problem, and how accessible different people or services are for adolescents. Questions were framed slightly differently for different categories of adolescents in order to be appropriate by age and marital status. We found that most girls cited female family members such as mothers, mothers-in-law, sisters, and elder female family members as their main sources of information and advice. Most participants who had sought assistance reported seeking help from doctors, village level health workers suc as ASHA and AWW, and medical stores. Table 4 summarizes the main sources of information and services for SRHR concerns, as reported by girls.

Among married girls in Rajasthan, reported sources of SRHR information varied from "official" sources like curricula and medical professionals, to family members and friends:

R7: We know all this through our education. It is there in the Class 10 science book.

R5: When I discuss [with] my mother, she tells me.

R2: And when we friends discuss such matters among ourselves, then we get such information.

R2: From my aunt and my grandmother.

R3: Even my sister-in-law tells me all this.

R6: From friends also we get such information.

-Married girls, aged 15-19, Rajasthan

Among unmarried girls aged 15-19 in Rajasthan, some reported receiving information from family members while others reported that they did not receive any SRHR informa- 
tion at all, or that they did not receive information specific to sexually transmitted infections:

R1: They don't get information from anybody.

R4: From sister-in-law.

R7: From sisters.

R8: From my elder sister.

R3: From friends.

R2: No, I just got from home.

R5: No, we haven't gotten information on burning sensation during urinating.

-Unmarried girls, aged 15-19, Rajasthan

In Bihar, some older unmarried girls (aged 15-19) reported receiving sexual and reproductive health information through adolescent education programs. These programs empower adolescents with accurate, age-appropriate, and culturally relevant information and promote knowledge about SRHR services including menstruation-related information, STIs, HIV/AIDS, contraceptives and pregnancy- related information, and healthy practices in school and from health workers.

R5: We are given sex education in our schools also. We are taught in our classrooms, we have another subject for sex education.

R6: From our friends.

R7: From our sisters.

R8: We get knowledge from the doctors; if we have any problem, then they solve it.

R9: When we go for the immunization, at that time ASHA also advise us.

-Unmarried girls, aged 15-19, Bihar

Some younger girls in Bihar (aged 12-14) reported family members as the primary source of information on menstruation. Others reported having no source for this information:

R7: Nobody told us.

I: You know about this, then who told you? How did you know about the monthly cycle?

R7: I heard from my sister.

I: Do you know who told you about this the first time?

From whom did you know about menstruation?

R2: My mother told me.

I: Who else told you?
R2: My sister told me.

R3: From the ASHA we got to know about this.

I: Other than the ASHA, did you hear from anywhere else?

R5: No.

-Unmarried girls, aged 12-14, Bihar

In addition to knowledge about health topics, we asked married girls where they can go when they need sexual and reproductive health services. Responses suggest that married girls go to the hospital, but they can also name other places to go for these types of services:

I: Where are girls like you going when they need health services?

R5: Hospital.

l: Hospital, where else?

R7: To "Baidya" (Practitioner of Ayurvedic medicine in village).

l: You are going to "Baidya" and hospital, where else girls like you are going for health-related services?

R4: Nowhere else.

R3: To Anganwadi Center.

I: To Anganwadi Center. Where else?

R4: ASHA. We also go to the ASHA sister.

R3: Yes, Anganwadi and ASHA sister.

-Married girls, aged 12-19, Odisha

In Rajasthan, married girls reported the hospital as the only location:

R1: From the hospital at times.

R6: We get it from the hospital.

R1: From the hospital.

R2: Only these.

R7: We tell our families, they get us treated.

-Married girls, aged 15-19, Rajasthan

\section{Mobility}

We know from previous research that girls' mobility relative to the mobility of their male peers tends to shrink at puberty (Hallman et al. 2015). We inquired about adolescent girls' mobility, seeking to understand where girls are allowed to go and how this is influenced by age and marital status. 
Among unmarried girls aged 15-19 in Jharkhand, girls reported being allowed to travel alone to a number of local places such as school, tuition centers, playground, Anganwadi center, tubewell, fields, and shops:

R7: Whenever there is a need we go to the block or the office alone.

R2: We go to the hand pump, well, temple alone. We even go to study alone at the school and the tutoring center.

R10: We even go to the college alone.

R6: We go to the river, playground, Anganwadi center, hand pump, and temple alone.

R7: Whenever we are not well and there is no one in the house to help us, then we go alone to the doctor.

R9: We go to the shop alone.

R6: We go to the farm alone.

-Unmarried girls, aged 15-19, Jharkhand

Similarly, younger unmarried girls in Bihar (aged 12-14) reported being allowed to go places alone:

R7: We go to the school and market alone. We go alone to the farm to work.

R1: We go to the shops and to the hand pump to fetch water.

R6: We go to pluck the grass.

R8: We go to the toilet.

R1: We go to the temple.

-Unmarried girls, aged 12-14, Bihar

In Odisha, some younger girls (aged 12-14) reported not being able to travel alone, which stood in stark contrast to what we heard in Bihar. Girls in Odisha reported that fears about safety explained why girls could not travel alone:

R7: No, girls don't go out alone.

R2: They fear [going alone].

R1: The family doesn't allow girls going alone. They may encounter some problem on the way.

-Unmarried girls, aged 12-14, Odisha
However, other girls in the same focus group reported that they were able to travel alone, suggesting that parents may not share the same views on their daughters' mobility or the same preoccupations about their safety. Some of the younger girls (aged 12-14) in Odisha reported numerous locations where they are able to travel alone:

R1: I go to school alone.

R3: We go to shop and some places [alone].

R4: I go alone to play.

R7: We go alone to bathe.

R6: We go to friend house.

R3: We go to bring water.

-Unmarried girls, aged 12-14, Odisha

Figure 2 shows girls' perceptions of what spaces within their community are considered safe for them. These data come from individual responses within focus groups. Although data from these groups is not typically quantified this way, Figure 2 provides an interesting overall view of how certain areas are perceived by adolescent girls. ${ }^{1}$ Overall, girls reported feeling safest at the well, the market, and tutoring centers, which are areas where a lot of women and girls are typically present. Locations mentioned less frequently, such as the toilets and carnivals/fairs may be seen as less safe because of the presence of men and boys. Interestingly, home, work and playgrounds were not included among the most frequently mentioned safe spaces.

There are a number of locations that girls consider to be unsafe. As a group of unmarried girls from Bihar noted, the ponds seem to be among the least safe spaces for girls.

I: You all said that you are afraid to go to the shop, market, and pond. Now tell me that out of these, which is the place where you are very afraid to go? Tell me out of the three places, where your fear is greatest?

R9: At the pond.

I: Why are you so afraid to go to these places? What is there that makes you scared? Tell us; if you will not tell us, then how will we come to know what makes you afraid? What is present there from which you are scared?

\footnotetext{
${ }^{1}$ It is important to note that these data are aggregated across locations and age groups and may not be representative of particular communities.
} 


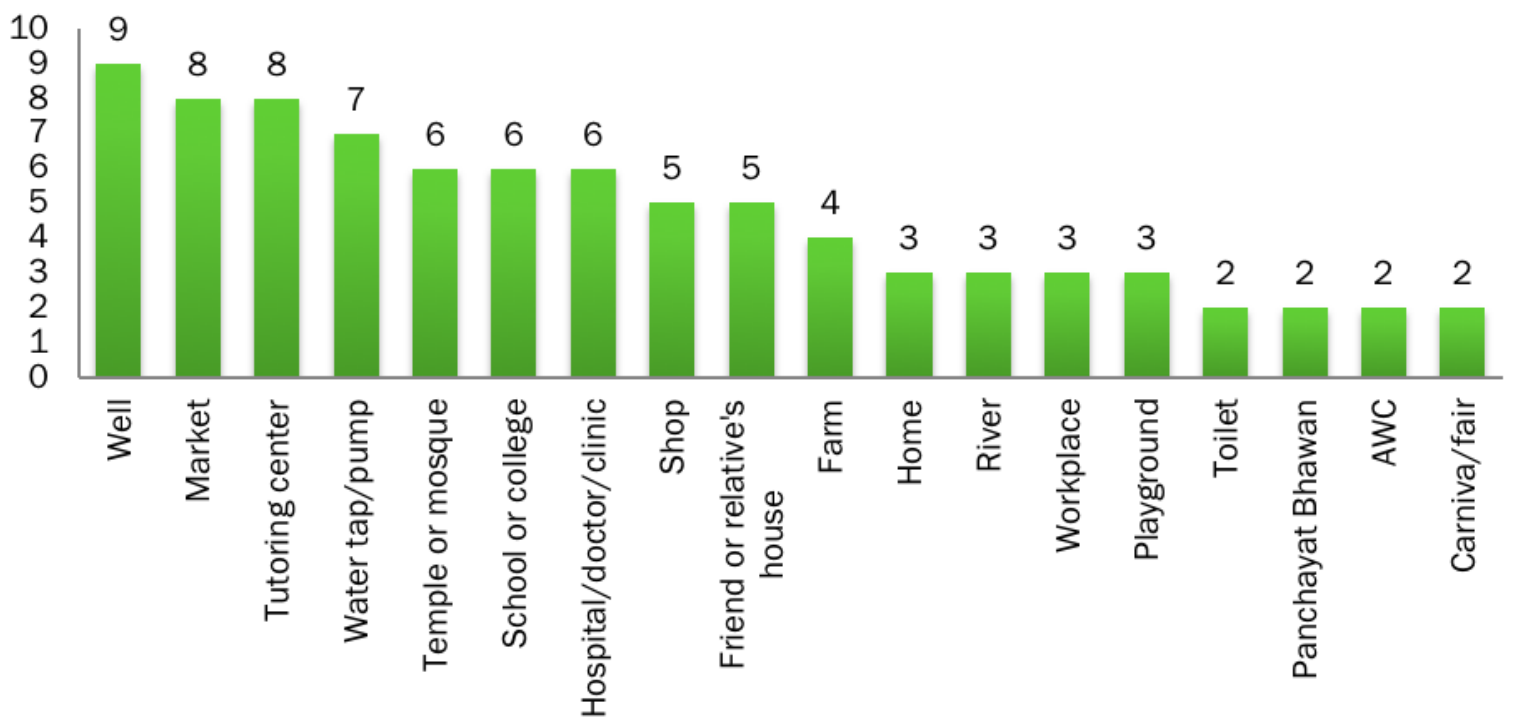

NOTE: Fifteen other places were each mentioned once.

AWC = Anganwadi center.

R3: Boys are there, so we hesitate to go to these places.

R7: Moreover, robbery is also there.

-Unmarried girls, aged 12-14, Bihar

Girls reported that they felt safe going to the temple and to school, largely because they are not alone in these places. The distance to a certain location was also an important factor in the perceived safety of that place, as girls in Jharkhand explained:

R2: The temple is just beside my house, that is why I am not afraid. There are many people around the temple, so I am not afraid to go there.

R1: We are not afraid to go to a place because we are with our friends. If there are many people surrounded around us, then we are not afraid.

R6: School is safe but the way to the school is not safe. We are afraid to pass that way.

R6: Temple is the safest. We can even go there by foot.

-Unmarried girls, aged 15-19, Jharkhand

\section{Sources of Support/Protection}

Part of the MTBA program strategy includes developing and supporting child-protection committees, so we asked girls about their knowledge of places they could go to get assistance if they wanted to avoid an early marriage. Married girls in Bihar and Rajasthan reported that they could go to a friend if they needed help. Parents were not recognized as a support system, and minor girls being forced into marriage were not aware of committees available to assist them:

I: So when girls are forced to get married in early age or with some such boy with whom they don't want to marry ... so in such situation do they seek help from somebody?

R4: Yes, they take some help.

R3: From their friend.

R6: Yes, somebody can ask help from friends or parents.

I: What do they say?

R5: They say they are not going to marry at this age, and few girls run away with boys of their own choice.

R1: They also say that they don't like this boy.

R2: Few guardians stop marriage as per their daughter's wish, but some don't.

R7: Nobody listen to girls.

R8: Yes, there is no such place from where they can get some help.

-Married girls, Bihar

I: They don't want to go against their parents.

R2: You also say something. What will happen if you will go against parents? 
R3: Nothing will happen.

I: Why can't you take help?

R2: They keep telling our parents that your daughter went against you. You did this.

-Married girls, Rajasthan

In Odisha, where very few girls reported early marriage instances, friends and parents were a key source of support when they didn't want to marry or wished to marry later.

I: A girl of your age, if she is getting married, is she married her own wish or not? And the groom is also by her choice or not, if a girl does not want to get married then she takes help from whom?

R2: Parents.

I: Except parents.

R1: Friends.

I: Any other.

R4: Anganwadi "didi."

-Unmarried girls, Rajasthan

Awareness about the child-protection committee was negligible in all study sites. Girls in this focus group went on to describe that there is no place for them to go to report an unwanted marriage because they do not have the right to refuse their families' wishes or to voice their disapproval.

In Jharkhand, one unmarried girl reported:

There isn't any facility available in our village where the girl can go and tell that she is forced to marry a boy against her will. There isn't any facility for the girls.

-Unmarried girl, Jharkhand

Others explained how refusing an arranged marriage could bring shame to their families:

R4: Because when the elders of our family decide [to marry a girl], then we cannot tell that we don't want to marry. We want to study and become prosperous; we think all this and keep this dream in our hearts. But when our parents tell us to marry, then we are not able to tell them about our dreams. We are not able to speak, so whatever is in our mind remains there.

R3: We are afraid that our parents will be ashamed in front of the community.
R10: We will be ashamed in front of the community, so we do not say anything.

R1: Yes, that's why we don't tell.

-Unmarried girls, Jharkhand

In Bihar, we heard that girls were aware of places they could go if they were going to be married early against their will. Unmarried girls in Bihar reported a number of sources for helping in their communities, including men, mothers, parents, brothers, teachers, friends, and Anganwadi workers.

I: Where do the young girls go if they are forced to marry at a very young age against their will? Do they go anywhere?

R1: Yes, they take help.

I: Okay, whom do they take help from?

R1: They take help from the men of the community and from their mothers.

R4: They take help from their teachers-they tell them their problems. They tell their friends also.

R5: They tell their mothers.

R9: They take help from the head of the village.

I: Where else do they take help?

R1: From the Anganwadi.

-Unmarried girls, Bihar 


\section{Discussion}

This research sheds light on the situation of adolescent girls in study communities and highlights some of the challenges faced in addressing early marriage.

Given the recent decline in early marriage as reported by UNICEF (2018) and increasing advocacy for enforcement of laws related to delaying marriage (Girls Not Brides 2016), we were interested in examining the knowledge and awareness of laws to understand whether and how these contribute to girls' and parents' decisions about the timing of marriage. We found mixed results related to community members' awareness of national laws prohibiting child marriage. Few respondents mentioned knowledge of the Compulsory Registration of Marriage Bill or the Dowry Prohibition Act, while knowledge of the Prohibition of Child Marriage Act was a bit higher. Respondents differed in their reports of how these laws influenced behavior, with some suggesting that threats of serious legal and even physical repercussions served as a deterrent, while others suggested that marriages occurred as they always had because "the people don't accept [the law]."

While the MTBA approach focuses on promoting alternative pathways to early marriage and childbearing, this study illustrates the important structural barriers that exist to such possibilities. We found that few girls in these areas are able to study beyond Class 8, as educational facilities beyond this level do not exist in their communities, and financial barriers combine with safety concerns to limit girls' opportunities for continuing their education at schools outside of their villages. We heard from girls and parents that very few girls in these communities continued education outside of their village because it was not financially viable. Parents also cited significant safety concerns related to girls traveling to schools outside of their villages. Interestingly, the reasons given for school discontinuation contrasted with what we found in the baseline survey where girls told us the primary reasons for school leaving were domestic responsibilities and gender norms against education for girls.

Beyond education, we found that there were limited livelihood opportunities available to girls. In some areas, girls work in the local industries such as brick factories and few reported participating in agricultural labor. Although parents report that this is not an ideal situation, it is among the few options for girls who need to earn a wage. In other areas, no livelihood opportunities are available to girls, so they focus solely on unpaid domestic responsibilities and their lives are contained to the household and associated duties. This reduced mobility is not uncommon as girls age (Hallman et al. 2015), but seemed particularly pronounced in some comments from parents. One father noted, "As there is no work available, why [should] girls go outside?" If programs like MTBA are to address delaying marriage, they need to work on creating viable alternatives for girls and helping parents and communities see girls for their value beyond domestic responsibilities. Programs must also address structural barriers to girls' education by providing safe transportation from villages to schools, for example, or by assisting needy families in covering educational costs.

We were interested in hearing from parents about social norms related to the timing of a girl's marriage and about reasons for early marriage in their communities. Parents reported that concerns about girls' reputations and sexual security have a strong impact on girls' freedom of movement and on the timing of their marriages. Parents discussed the need to ensure that their daughters are married at the optimal moment-when they are not too young and not too old-since both extremes have important social (and sometimes health) repercussions. Some parents also reported that their own economic situation influenced the timing of their daughter's marriage, with marriage delayed due to the inability to afford gauna.

\section{Program Recommendations}

These findings reveal several considerations that should be taken into account by those designing activities to delay marriage in these communities:

- Programs need to recognize the limited alternative pathways to early marriage at the community level and may need to carve out new alternatives. We heard from many participants that higher education was not possible in many communities and that wage work was limited. Programs may need to work with local stakeholders to consider what economic activities 
may be viable for adolescent girls, what new economic spaces may be developed to engage girls, and how girls entering limited wage-work spaces may have the effect of displacing others, with unintended consequences. Careful and considerate approaches are needed to find livelihood opportunities for girls, and small pilot studies may be useful in providing direction in this area.

- Knowledge of laws is limited, but where they are known, responses to these laws focus more on the perceived harsh repercussions for violating them and less on the reasoning behind the law or the need to protect girls from early marriage. Participants spoke of the punishments as a deterrent but did not engage as deeply with the idea that early marriage is a harmful practice for girls. Programs need to address how best to educate communities about the rationale behind these laws and about how criminalizing early marriage without bolstering arguments for the alternatives may have unintended consequences like driving marriages underground or delaying marriages until age 18 without improving the circumstances for adolescent girls in those communities.

- In areas where gauna is practiced, we have limited knowledge of how this contributes to early marriage including how extended periods of gauna may mask early marriage statistics. Programs may also consider taking advantage of long gauna periods as a means of working with girls and couples prior to their official marriage, providing valuable information about birth spacing and contraceptives, gender equitable attitudes, healthy conflict resolution, and other topics. 


\section{References}

Basu, S., R. Acharya, A.J. Melnikas, and S. Amin. 2017. More than Brides Alliance: Baseline Report, India. New York: Population Council. https://www.popcouncil.org/research/ testing-effective-approaches-to-end-child-marriage.

Erulkar, Annabel and Abebaw Ferede. 2009. "Social exclusion and early or unwanted sexual initiation among poor urban females in Ethiopia," International Perspectives on Sexual and Reproductive Health 35(4): 186-193.

Erulkar, Annabel and Tekle-Ab Mekbib. 2007. "Invisible and vulnerable: Adolescent domestic workers in Addis Ababa, Ethiopia," Vulnerable Children and Youth Studies 2(3): 246-256.

Girls Not Brides. 2016. The Role of Parliamentarians in Ending Child Marriage. https://www.girlsnotbrides.org/ resource-centre/the-role-of-parliamentarians-in-ending-child-marriage/.

Girls Not Brides. 2018. A Theory of Change on Child Marriage. https://www.girlsnotbrides.org/child-marriagetheory-of-change/.

Hallman, K.K., N.J. Kenworthy, J. Diers, N. Swan, and B. Devnarain. 2015. "The shrinking world of girls at puberty: Violence and gender-divergent access to the public sphere among adolescents in South Africa," Global Public Health 10(3): 279-295. https://dx.doi.org/10.1080 \%2F17441692.2014.964746

International Institute for Population Sciences (IIPS) and ICF.2017. National Family and Health Survey (NFHS4),2015-16: India Mumbai: IIPS http://rchiips.org/nfhs/ NFHS-4Reports/India.pdf

Nanda P. and P. Das. 2015. Making Change with Cash? Impact of a Conditional Cash Transfer Program on Age of Marriage In India. International Center for Research on Women (ICRW). Accessed 28 November 2017. https://www. icrw.org/wp-content/uploads/2016/10/IMPACCT_CCTBrief_ webready.pdf
Narayan, D. 2018. “India's abuse of women is the biggest human rights violation on Earth," The Guardian. April 27, 2018. https://www.theguardian.com/commentisfree/2018/apr/27/india-abuse-women-human-rights-rapegirls

Parsons, Jennifer and Jennifer McCleary-Sills. 2014. Preventing child marriage: Lessons from World Bank Group Gender Impact Evaluations (English). enGender Impact: the World Bank's Gender Impact Evaluation Database. Washington, DC: World Bank Group. http://documents. worldbank.org/curated/en/224441468147543361/pdf/899890BRIOenGEOBox0385238BOOPUBLICO.pdf http://documents.worldbank.org/curated/ en/224441468147543361/Preventing-child-marriage-lessons-from-World-Bank-Group-gender-impact-evaluations.

Raj, A. 2010. "When the mother is a child: The impact of child marriage on the health and human rights of girls," Archives of Disease in Childhood 95: 931-935.

Santhya, K.G., N. Haberland, and A.K.Singh. 2006. “'She only knew when the garland was put around her neck': Findings from an exploratory study on early marriage in Rajasthan." New Delhi: Population Council

UNICEF. 2018. Child Marriage: Latest trends and future prospects. https://data.unicef.org/resources/childmarriage-latest-trends-and-future-prospects/. 